\title{
GMR
}

\section{Growth curves of carcass traits obtained by ultrasonography in three lines of Nellore cattle selected for body weight}

\author{
C.C. Coutinho', M.E.Z. Mercadante', A.M. Jorge', C.C.P. Paz ${ }^{2}$, L. El Faro² and \\ F.M. Monteiro² \\ ${ }^{1}$ Faculdade de Medicina Veterinária e Zootecnia, Fazenda Experimental Lageado, \\ Universidade Estadual “Júlio de Mesquita Filho", Botucatu, SP, Brasil \\ ${ }^{2}$ Centro APTA Bovinos de Corte, Instituto de Zootecnia, Sertãozinho, SP, Brasil
}

Corresponding author: M.E.Z. Mercadante

E-mail: mercadante@iz.sp.gov.br / mezmercadante@gmail.com

Genet. Mol. Res. 14 (4): 14076-14087 (2015)

Received May 14, 2015

Accepted August 13, 2015

Published October 29, 2015

DOI http://dx.doi.org/10.4238/2015.October.29.27

\begin{abstract}
The effect of selection for postweaning weight was evaluated within the growth curve parameters for both growth and carcass traits. Records of 2404 Nellore animals from three selection lines were analyzed: two selection lines for high postweaning weight, selection (NeS) and traditional $(\mathrm{NeT})$; and a control line $(\mathrm{NeC})$ in which animals were selected for postweaning weight close to the average. Body weight (BW), hip height $(\mathrm{HH})$, rib eye area (REA), back fat thickness (BFT), and rump fat thickness (RFT) were measured and records collected from animals 8 to 20 (males) and 11 to 26 (females) months of age. The parameters $A$ (asymptotic value) and $\mathrm{k}$ (growth rate) were estimated using the nonlinear model procedure of the Statistical Analysis System program, which included fixed effect of line ( $\mathrm{NeS}, \mathrm{NeT}$, and $\mathrm{NeC}$ ) in the model, with the objective to evaluate differences in the estimated parameters between lines. Selected animals ( $\mathrm{NeS}$ and $\mathrm{NeT}$ ) showed higher growth rates than control line animals $(\mathrm{NeC})$ for all traits. Line effect on curves parameters was significant $(P<0.001)$ for BW, $\mathrm{HH}$, and REA in males, and for BFT and RFT in females. Selection
\end{abstract}


for postweaning weight was effective in altering growth curves, resulting in animals with higher growth potential.

Key words: Fat thickness; Longissimus muscle area; Nonlinear models; Selection; Nellore cattle

\section{INTRODUCTION}

In an attempt to improve the productive performance of herds, genetic improvement programs for beef cattle have focused on growth traits that can be easily measured with high accuracy, such as weight at certain ages or weight gain (Yokoo et al., 2008). However, in view of current consumer demands for improvements in the quality of the final product, focus on carcass traits such as loin eye area and subcutaneous fat thickness has become very important; the use of ultrasonography is fundamental for this purpose (Reverter et al., 2000; MacNeil and Northcutt, 2008).

Selection of animals based on growth traits can lead to changes in the growth curve (Lopes et al., 2012). Several investigators have employed nonlinear models in studies of the growth of beef cattle using weights over time (Brown et al., 1976; Perotto et al., 1992; Lopes et al., 2012). However, investigations of development of carcass traits as a function of animal age using nonlinear models are rare.

Nonlinear models are adequate to describe the growth of beef cattle because they contain parameters with biological interpretations. Two parameters are particularly important for the identification of more efficient animals within a production system: parameter $A$, defined as the asymptotic value of the trait when $t$ (time, age) tends to infinity; and parameter $k$, interpreted as the rate of growth or maturation which indicates the growth rate of the trait until adult age (Quirino et al., 1999; Paz et al., 2004a; Forni et al., 2007; Loiza-Echeverri et al., 2013). Growth curves that relate weight or height, to animal age have been used widely to describe the growth of Nellore cattle (Forni et al., 2009; Lopes et al., 2012), but little has been reported regarding the growth curve of carcass traits.

The objectives of the present study were to: describe the growth curves of body weight (BW), hip height $(\mathrm{HH})$, rib eye area (REA), backfat thickness (BFT) and rump fat thickness (RFT) in Nellore cattle 8 to 26 months of age belonging to three lines selected for postweaning weight; and verify the effect of selection for postweaning weight on growth curves for these traits.

\section{MATERIAL AND METHODS}

\section{Animals, management and data structure}

The experiment was conducted in accordance with animal welfare guidelines set out in State Law No. 11977 of the State of São Paulo, Brazil.

The database used referred to the Nellore herd of Centro de Bovinos de Corte, Instituto de

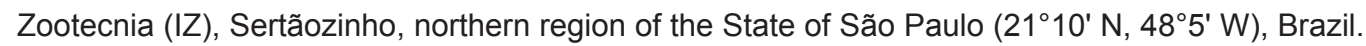
The herd consisted of three lines selected for postweaning weight. In two of the selection lines, selection (NeS) and traditional (NeT), animals were selected for higher individual performance of postweaning weight (378 days of age for males and 550 days of age for females), while in the so-called control line $(\mathrm{NeC})$ animals with a postweaning weight performance close to the average were selected (stabilizing selection). In the three lines, selection has been performed within the 
contemporary group (selection line x year of birth) since 1980 (Mercadante et al., 2003).

The $\mathrm{NeC}$ and $\mathrm{NeS}$ lines were basically managed in the same environment, while the $\mathrm{NeT}$ line was managed on the same farm, but in different lots. As a consequence, the difference between $\mathrm{NeS}$ and $\mathrm{NeT}$ was essentially environmental, while the difference between $\mathrm{NeC}$ and $\mathrm{NeS}$ was essentially genetic (Cyrillo et al., 2000). Animals were kept on Brachiaria brizantha (Urochloa spp) pasture. Males were weaned at 7 months of age, following which they were sent for feedlot performance testing, where they remained for 5.5 months (April to October). Females were also weaned at 7 months, but remained on pasture until they reached 550 days of age; they were then selected for exposure to bulls at 26 months of age. There were exception of females born in 2004 and 2005 ( $\mathrm{NeC}$ and $\mathrm{NeS}$ lines) and females born from 2008 to 2011 (NeT line), which they were sent for feedlot performance test after weaning for 4 months. All animals received mineral salt and protein supplementary feeding during the dry season.

The dataset used included records from 2404 Nellore animals (1256 males and 1148 females) and comprised BW, HH, REA, BFT and RFT measurements from males and BFT and RFT measurements from females. Males included in the dataset were born in 1996, 1997, 1999, 2001 and 2002, or between 2005 and 2011, and females were born between 2003 and 2011. Figures 1 and 2 show the number of observations and means observed for the traits, as a function of age for the three lines ( $\mathrm{NeC}, \mathrm{NeS}$ and $\mathrm{NeT})$.
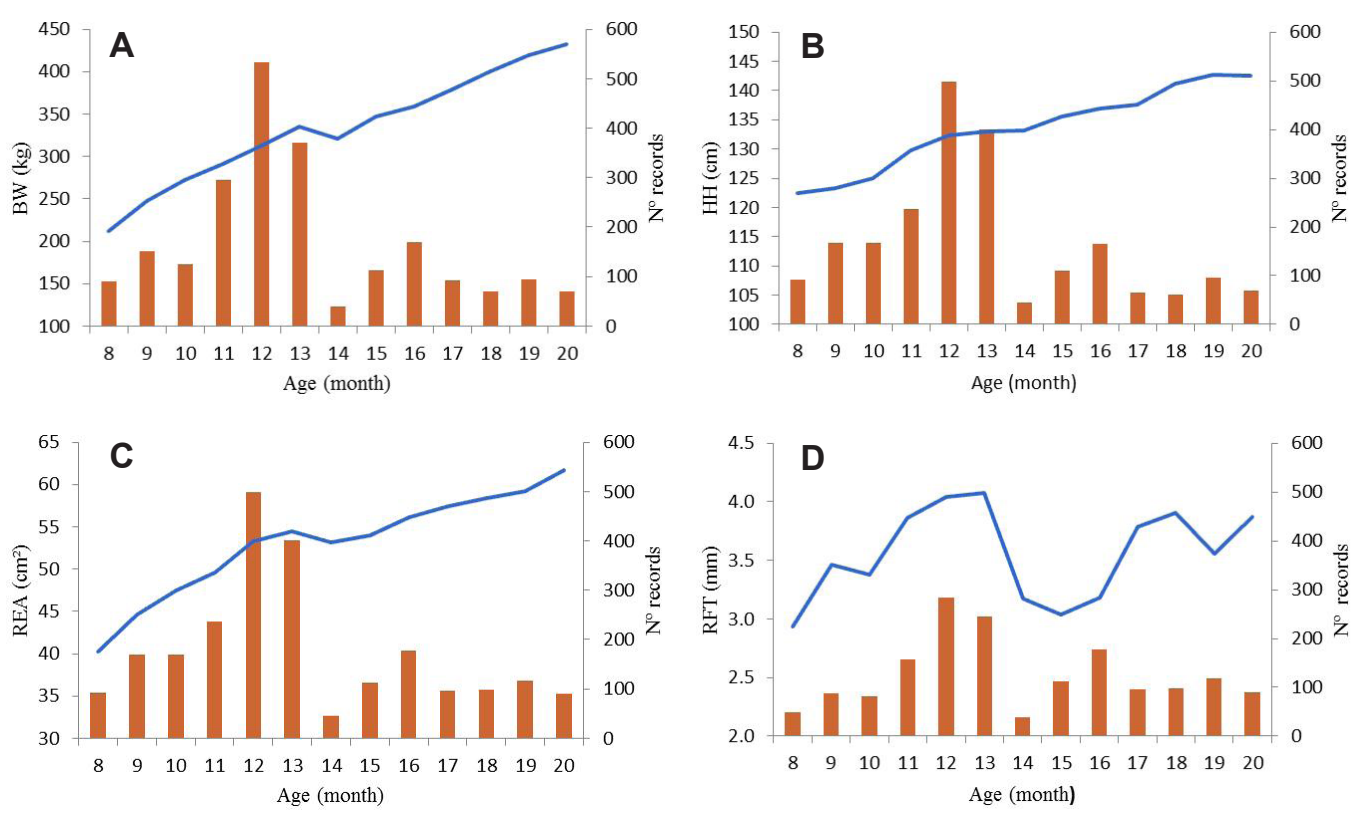

Figure 1. Records and means for traits as a function of age in male cattle. Number of records (bar) and means (line) of (A) body weight (BW), (B) hip height $(\mathrm{HH}),(\mathbf{C})$ rib eye area (REA) and (D) rump fat thickness (RFT).

Images for REA, BFT and RFT were collected and stored using a Pie Medical 401347-Aquila ultrasound apparatus (Pie Medical Equipment B.V., Maastricht, Netherlands) equipped with a linear 3.5-MHz $18 \mathrm{~cm}$ probe. For measurement of REA and BFT, the transducer was placed perpendicular to the spine between the 12 and 13th ribs on the left side of the animal using a standoff pad. For measurement of RFT, the transducer was placed at the intersection between the 
gluteus medius and biceps femoris muscles, between the hook and pin bones. Vegetable oil was used as the coupling agent. Measurements were obtained using the program Echo Image Viewer 1.0 (Pie Medical Equipment B.V., Maastricht, Netherlands, 1996). Hip height was measured using measuring tapes installed inside the scale and was defined as the distance between the anterior portion of the sacral bone and the ground.

As seen in Figure 1, records of the traits analyzed in males were concentrated from 11 to 13 months of age, a period during which animals were weighed for selection at the end of the performance test. Following this, some animals were sold, and others finished and slaughtered (approximately $8 \%$ of animals). The mean BFT of males and females in the three lines exhibited wide variation over the ages studied, and was the trait most susceptible to the environmental effect of season (Figures 1 and 2).
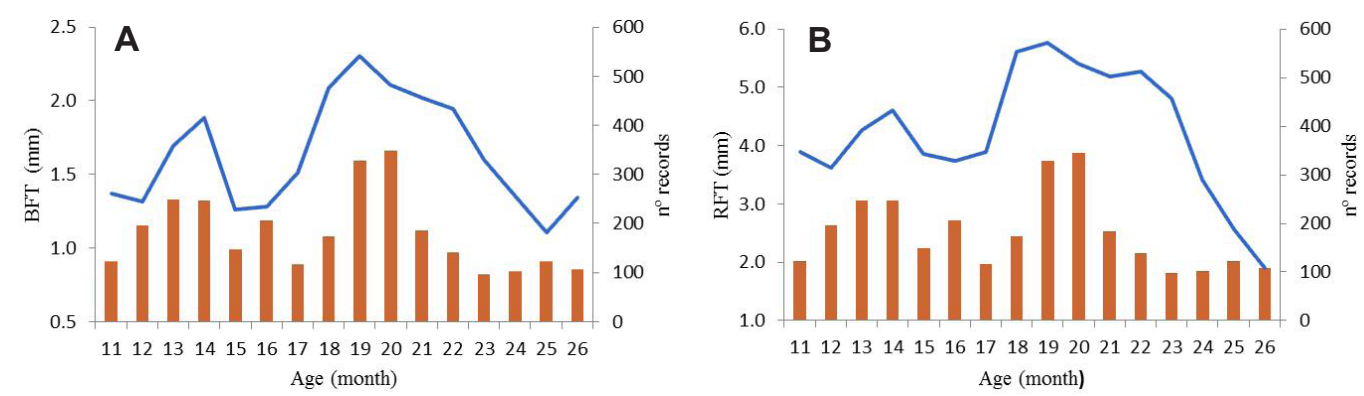

Figure 2. Records and means for traits as a function of age in female cattle. Number of records (bar) and means (line) of (A) backfat thickness (BFT) and (B) rump fat thickness (RFT).

\section{Statistical analysis}

Brody (Brody, 1945), von Bertalanffy (von Bertalanffy, 1957), logistic (Nelder, 1961), and Gompertz (Laird, 1965) models were fitted to identify the best model to describe the average growth curve of the lines for each trait studied. The interactive Gauss-Newton method described by Hartley (1961) was used to fit data and to estimate growth parameters by means of nonlinear models, using the NLIN procedure of the program Statistical Analysis System (SAS Institute, Inc., Cary, NC), with a convergence criterion of $10^{-8}$.

The following nonlinear models were used:

Brody:

$$
y_{t}=A\left(1+b e^{-k t}\right)
$$

von Bertalanffy:

$$
y_{t}=A\left(1+b e^{-k t}\right)^{3}
$$

logistic:

$$
y_{t}=A\left(1+b e^{-k t}\right)^{-m}
$$

Gompertz:

$$
y_{t}=A e^{-b e \exp (-k t)}
$$

Within the models, $y_{\mathrm{t}}$ was the trait observed at age $t$ (in months); $A$ was the asymptotic value of the trait when $t$ (age) tended to infinity; $B$ was a constant of integration without biological 
interpretation and was established by the values of the trait at age zero; $k$ was the rate of maturation and indicated tissue growth rate until adult age (thus, the higher this value, the more precocious the animal in terms of the growth trait studied); and $m$ determined the shape of the growth curve and, consequently, the point of inflection at which the phase of deceleration started until the adult measure was reached (Quirino et al., 1999; Paz et al., 2004a; Forni et al., 2007; Loaiza-Echeverri et al., 2013).

In the case of the present study, no records of the traits were available after 26 months of age. Therefore, the adult measure was not reached and parameter $A$ reflected an estimate of the measure for the last assessments.

Goodness-of-fit of the nonlinear models was evaluated using the criteria convergence of the model; mean square error (MSE); and coefficient of determination $\left(R^{2}\right)$. After choosing the best model for all traits studied, records for each trait were corrected for the effect of contemporary group by the least square method, taking the residuals (yres). The residuals were then added to the observed mean of each respective age class (in months) for the trait studied.

The application of nonlinear models showed the influence of line on the growth curve of the traits as a function of age considering two models. The first model, called 'reduced', assumed the absence of differences between lines ( $\mathrm{NeC}, \mathrm{NeS}$ and $\mathrm{NeT}$ ). Hence, only a set of estimated parameters $(A, b$, and $k)$ would be necessary to define the average growth curve of the trait analyzed for the three lines. The second model, called 'full', assumed the existence of differences between lines. Hence, different sets of estimated parameters were necessary to define three growth curves, one for each line (Paz et al., 2004b).

To determine whether a difference existed between the reduced and full models - that is, to evaluate the need of modeling distinct curves for each line - the lack-of-fit test was applied using the observed $F$ ratio (Equation 5). The PROBF function (SAS Institute, Inc., Cary, NC) was used to calculate the observed $F$ value (Fobs), which returns the probability of an $F$ distribution, with the degrees of freedom of the numerator being equal to DFR ${ }_{\text {reduced }}-D_{F} R_{\text {full }}$ and the degrees of freedom

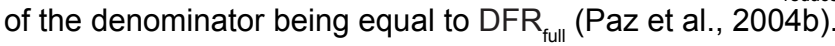

$$
\mathrm{F}_{\text {obs }}=\frac{\left(\mathrm{SSR}_{\text {reduced }}-\mathrm{SSR}_{\text {full }}\right) /\left(\mathrm{DFR}_{\text {reduced }}-\mathrm{DFR}_{\text {full }}\right)}{\mathrm{MSE}_{\text {full }}} \quad \text { (Equation 5) }
$$

For Equation 5, the probability of the observed $F$ ratio: Prob $>F=1-\operatorname{ProbF}\left\{F_{\text {obs }}\right.$, [DFR ${ }_{\text {reduced }}$ - DFR full, [DFR full]\}, where $S S R_{\text {reduced }}$ was the residual sum of squares of the reduced model; $S S R_{\text {full }}$ was the residual sum of squares of the full model; $\mathrm{MSE}_{\text {full }}$ was the residual mean squared error of the full model; DFR ${ }_{\text {reduced }}$ was the residual degrees of freedom of the reduced model; $D_{F} R_{\text {full }}$ was the residual degrees of freedom of the full model.

For all studied traits, it was necessary to use the full model (one curve for each line). Since the effect of line on the growth curve parameters was significant $(P<0.05)$, pairwise comparisons ( $\mathrm{NeC}$ versus $\mathrm{NeS}, \mathrm{NeC}$ versus $\mathrm{NeT}$, and $\mathrm{NeS}$ versus $\mathrm{NeT}$ ) of the curves estimated for each line were performed using PROC NLIN and the lack-of-fit test.

\section{RESULTS}

For the traits analyzed in males, the Brody model showed the best fit among the nonlinear models studied to describe the average growth curve of the lines for $\mathrm{BW}, \mathrm{HH}$, and REA; this model had the lowest MSE and highest $\mathrm{R}^{2}$. For RFT in males, and BFT and RFT in females, the logistic model showed the best fit (Table 1). 
Table 1. Parameter estimates by Brody and logistic models, coefficient of determination $\left(R^{2}\right)$ and mean square error (MSE) for growth and carcass traits of male and female cattle.

\begin{tabular}{|c|c|c|c|c|c|c|}
\hline Trait $^{a}$ & Model & $A^{b}$ & b & k & $\mathrm{R}^{2}$ & MSE \\
\hline \multicolumn{7}{|l|}{ Males } \\
\hline BW (kg) & BRODY & 535.1 & 1.1341 & 0.0828 & 0.9837 & $1,766.2$ \\
\hline $\mathrm{HH}(\mathrm{cm})$ & BRODY & 151.3 & 0.4463 & 0.1013 & 0.9984 & 28.1043 \\
\hline $\operatorname{REA}\left(\mathrm{cm}^{2}\right)$ & BRODY & 60.71 & 1.9515 & 0.2212 & 0.9783 & 62.3708 \\
\hline $\mathrm{RFT}(\mathrm{mm})$ & LOGISTIC & 3.73 & $16,576.9$ & 1.3726 & 0.8473 & 2.4524 \\
\hline \multicolumn{7}{|l|}{ Females } \\
\hline $\mathrm{BFT}(\mathrm{mm})$ & LOGISTIC & 1.8421 & 65.8597 & 0.4593 & 0.6366 & 1.7320 \\
\hline RFT (mm) & LOGISTIC & 4.6847 & 68.7019 & 0.4897 & 0.7516 & 6.6814 \\
\hline
\end{tabular}

aBW, body weight; $\mathrm{HH}$, hip height; REA, rib eye area; BFT, backfat thickness; and RFT, rump fat thickness. ${ }^{\mathrm{b}} \mathrm{A}$, asymptotic value; $b$, constant of integration; $k$, growth rate (function of age in months).

Analysis of BFT in males did not reach convergence with the models tested. This finding may be explained by the fact that most male Nellore animals in this age range (up to 20 months) did not develop subcutaneous fat (most records were close to zero and $29 \%$ (677 observations) were zero); hence, no normal distribution of the data was observed.

Estimates of the growth curve parameters $(A, b, k)$ for the Brody and logistic models, coefficient of determination of the model, comparison between lines, and probability of the $F$ test are shown in Table 2 for each line. The models showed a good fit to the dataset, with a coefficient of determination higher than $85 \%$ for male traits, with the exception of fat thickness in females.

Table 2. Parameter estimates, residual degrees of freedom (DFR), coefficient of determination $\left(R^{2}\right)$, comparison between lines (COMP) and the probability of $F$ value ( $P r o b>F)$ for growth and carcass traits of male and female cattle.

\begin{tabular}{|c|c|c|c|c|c|c|c|c|}
\hline Trait $^{\mathrm{a}}$ & LINE $^{b}$ & $A^{c}$ & b & k & DFR & $\mathrm{R}^{2}$ & COMP & Prob $>$ F \\
\hline \multicolumn{9}{|l|}{ Males } \\
\hline & $\mathrm{NeC}$ & 370 & 3.6076 & 0.2165 & 320 & 0.9785 & $\mathrm{NeC}$ vs $\mathrm{NeS}$ & $<0.0001$ \\
\hline \multirow[t]{3}{*}{ BW (kg) } & $\mathrm{NeS}$ & 446 & 4.1397 & 0.2296 & 680 & 0.9810 & $\mathrm{NeC}$ vs $\mathrm{NeT}$ & $<0.0001$ \\
\hline & $\mathrm{NeT}$ & 463 & 3.1133 & 0.1945 & 1204 & 0.9819 & $\mathrm{NeS}$ vs $\mathrm{NeT}$ & 0.341 \\
\hline & $\mathrm{NeC}$ & 136 & 0.9318 & 0.2074 & 310 & 0.9985 & $\mathrm{NeC}$ vs $\mathrm{NeS}$ & $<0.0001$ \\
\hline \multirow[t]{3}{*}{$\mathrm{HH}(\mathrm{cm})$} & $\mathrm{NeS}$ & 145 & 1.6748 & 0.2544 & 680 & 0.9984 & $\mathrm{NeC}$ vs $\mathrm{NeT}$ & $<0.0001$ \\
\hline & $\mathrm{NeT}$ & 145 & 1.5813 & 0.2502 & 1176 & 0.9984 & $\mathrm{NeS}$ vs $\mathrm{NeT}$ & 0.615 \\
\hline & $\mathrm{NeC}$ & 59.5 & 8.2068 & 0.3324 & 321 & 0.9801 & $\mathrm{NeC}$ vs $\mathrm{NeS}$ & $<0.0001$ \\
\hline \multirow[t]{3}{*}{$\operatorname{REA}\left(\mathrm{cm}^{2}\right)$} & $\mathrm{NeS}$ & 59.9 & 17.1311 & 0.4369 & 688 & 0.9809 & $\mathrm{NeC}$ vs $\mathrm{NeT}$ & $<0.0001$ \\
\hline & $\mathrm{NeT}$ & 60.2 & 16.3062 & 0.4272 & 1287 & 0.9801 & $\mathrm{NeS}$ vs $\mathrm{NeT}$ & 0.968 \\
\hline & $\mathrm{NeC}$ & 4.02 & 1269.1 & 0.7936 & 205 & 0.8503 & $\mathrm{NeC}$ vs $\mathrm{NeS}$ & 0.078 \\
\hline \multirow[t]{2}{*}{$\mathrm{RFT}(\mathrm{mm})$} & $\mathrm{NeS}$ & 3.73 & 6633.7 & 1.0402 & 478 & 0.8922 & $\mathrm{NeC}$ vs $\mathrm{NeT}$ & 0.072 \\
\hline & $\mathrm{NeT}$ & 3.86 & 47719.6 & 1.3695 & 937 & 0.8552 & $\mathrm{NeS}$ vs $\mathrm{NeT}$ & 0.183 \\
\hline \multicolumn{9}{|l|}{ Females } \\
\hline & $\mathrm{NeC}$ & 1.94 & 24.8576 & 0.2781 & 483 & 0.7136 & $\mathrm{NeC}$ vs $\mathrm{NeS}$ & 0.0205 \\
\hline \multirow[t]{3}{*}{$\mathrm{BFT}(\mathrm{mm})$} & $\mathrm{NeS}$ & 1.68 & 37.4125 & 0.3870 & 961 & 0.6598 & $\mathrm{NeC}$ vs $\mathrm{NeT}$ & $<0.0001$ \\
\hline & $\mathrm{NeT}$ & 2.15 & 830.5 & 0.6026 & 1438 & 0.6912 & $\mathrm{NeS}$ vs $\mathrm{NeT}$ & $<0.0001$ \\
\hline & $\mathrm{NeC}$ & 4.52 & 44.7231 & 0.3482 & 484 & 0.7698 & $\mathrm{NeC}$ vs $\mathrm{NeS}$ & 0.144 \\
\hline \multirow[t]{2}{*}{ RFT (mm) } & $\mathrm{NeS}$ & 4.24 & 31.1526 & 0.3787 & 957 & 0.7559 & $\mathrm{NeC}$ vs $\mathrm{NeT}$ & $<0.0001$ \\
\hline & $\mathrm{NeT}$ & 5.54 & 273.4 & 0.5385 & 1435 & 0.8137 & $\mathrm{NeC}$ vs $\mathrm{NeT}$ & $<0.0001$ \\
\hline
\end{tabular}

aBW, body weight; $\mathrm{HH}$, hip height; REA, rib eye area; $\mathrm{BFT}$, backfat thickness; and RFT, rump fat thickness. ${ }^{\mathrm{b}} \mathrm{NeC}$, control line; $\mathrm{NeS}$, selection line; $\mathrm{NeT}$, traditional line; ${ }^{\mathrm{A}} \mathrm{A}$, asymptotic value; $\mathrm{b}$, constant of integration; $\mathrm{k}$, growth rate (function of age in months).

Parameter $A$ was higher for males of lines $\mathrm{NeS}$ and $\mathrm{NeT}$ compared to males of line $\mathrm{NeC}$, except for the trait RFT. For HH and REA in males, and BFT and RFT in females, the growth rate 
(k) was also higher for lines submitted to the same selection scheme ( $\mathrm{NeS}$ and $\mathrm{NeT}$ ) compared to $\mathrm{NeC}$. The growth rate for BW was similar for all three lines (Table 2).

Figure 3 illustrates the growth curves of BW, HH, REA and RFT as a function of age in months, fitted with the Brody model, for males of lines $\mathrm{NeC}, \mathrm{NeS}$ and $\mathrm{NeT}$. The lack of pre weaning records and records after 20 months of age for males may explain the ascending trend of the growth curve in animals from the three lines, since these animals were still growing and had not yet reached maturity.
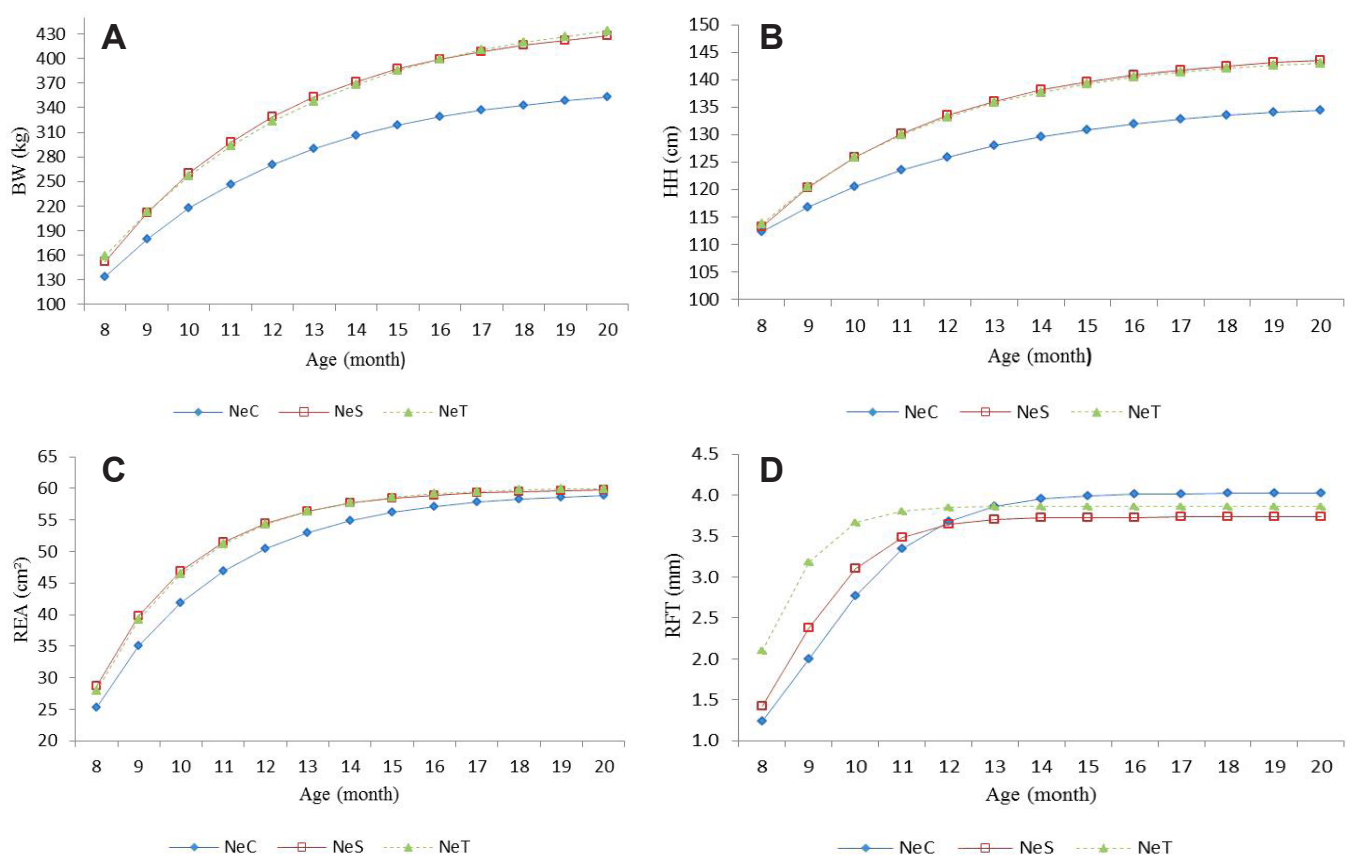

Figure 3. Growth curves of traits in male cattle, fitted with the logistic model. (A) Body weight (BW), (B) hip height (HH), (C) rib eye area (REA), and (D) rump fat thickness (RFT) of control (NeC), selection (NeS) and traditional (NeT) cattle lines.

The differences in $\mathrm{BW}$ and $\mathrm{HH}$ observed between lines submitted to the same selection scheme ( $\mathrm{NeS}$ and $\mathrm{NeT}$ ) and $\mathrm{NeC}$ increased with increasing age of the animal. The initial weight of selected animals before entering the performance test at an average age of 8 months indicated a difference of more than $15 \mathrm{~kg}(\mathrm{NeC}=134 \mathrm{~kg}, \mathrm{NeS}=152 \mathrm{~kg}$, and $\mathrm{NeT}=159 \mathrm{~kg})$ compared to control animals. The growth rate of $\mathrm{HH}$ decreased after 17 months, probably because animals had almost reached maximum bone growth (Figure $3 \mathrm{~A}$ and $\mathrm{B}$ ).

Growth of REA was intense in the period immediately following weaning. After 15 months of age, growth of REA decreased in animals from the three lines, causing the curves to approach each other by 20 months of age (Figure $3 \mathrm{C}$ ). For the $\mathrm{NeS}$ and $\mathrm{NeT}$ lines, parameters estimated with the Brody model did not differ significantly (Table 2) and growth curves of REA of these lines were overlapping. The same could be observed for growth curves of BW and $\mathrm{HH}$ (Figure $3 \mathrm{~A}$ and B).

With respect to fat thickness in males, greater RFT accumulation was observed from 8 to 12 months of age (Figure $3 \mathrm{D}$ ), the period during which animals underwent performance testing. A decline in the growth rate and stabilization were observed following this period. This decrease after 12 months may be due to the fact that animals were transferred to pasture after the performance 
test, which is of lower nutritional value than feedlot rations. Additionally, animals were at the onset of puberty, a period characterized by an increase in male hormones and reduction in fat deposition.

Growth curves of BFT and RFT in females, fitted with the logistic model, are shown in 4. The difference between $\mathrm{NeT}$ and the other two lines was attributed to environmental effect since some of the NeT females were submitted to performance test after weaning and received a diet different from that of animals that remained on pasture. With respect to the $\mathrm{NeC}$ and $\mathrm{NeS}$ lines which were always under the same nutritional management, higher fat deposition was observed in $\mathrm{NeC}$ animals, which differed significantly for BFT $(P=0.0205)$, but not RFT $(P=0.144)$.
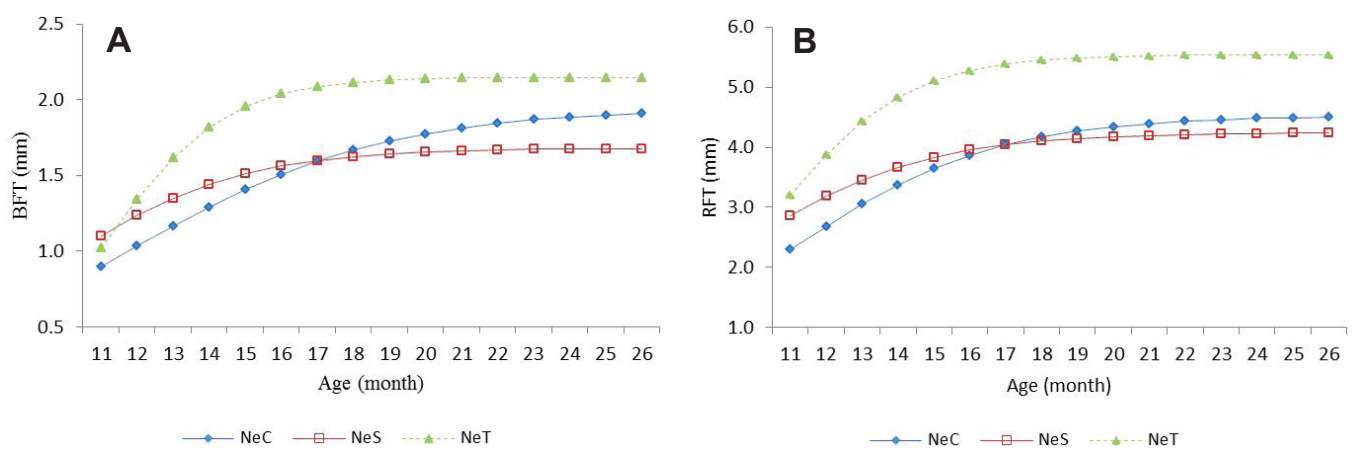

Figure 4. Growth curves of traits in female cattle, fitted with the logistic model. (A) Backfat thickness (BFT) and (B) rump fat thickness (RFT) from control $(\mathrm{NeC})$, selection $(\mathrm{NeS})$ and traditional $(\mathrm{NeT})$ cattle lines.

\section{DISCUSSION}

There are divergences in the literature regarding the choice of the best nonlinear model to describe cattle growth. Some studies suggest the Brody function is most appropriate due to its computational simplicity, interpretability of parameters, and model convergence (Arango and van Vleck, 2002; Forni et al., 2009).

According to Paz et al. (2004a), the logistic model is adequate to describe the growth of animals that have not yet reached maturity, since it contains a more variable inflection point than other models. This hypothesis was supported by findings in the present study, in which the logistic model showed the best fit to describe growth curves of BFT and RFT.

The selection for postweaning weight caused changes in growth traits (weight, gain, growth rate), including a significant difference in weight between growth curves of selected (NeS and $\mathrm{NeT}$ ) and control ( $\mathrm{NeC}$ ) animals. This difference of more than $15 \mathrm{~kg}$ in the initial weight of selected animals before entering performance test compared to control animals was similar to that reported by Bonilha et al. (2008) who evaluated 9 years of the Nellore line of IZ before animals entered the finishing phase, demonstrating that an animal selected for postweaning weight is also superior in terms of post-selection weights.

The process of selection applied to the animals resulted in an estimated average genetic change of $62 \mathrm{~kg}$ in weight adjusted for 378 days of age (W378) in the NeS line compared to the $\mathrm{NeC}$ line. The estimated annual genetic progress in W378 was $0.57 \%$ and $0.77 \%$ of the average/ year in the NeS and NeT lines, respectively (Mercadante et al., 2003). Several studies have shown that selection of cattle for postweaning weight promotes greater live weight, higher weight gain per metabolizable energy and higher carcass weight, in addition to higher retail cut yield (Koch et al., 2004; Altarriba et al., 2005; Bonilha et al., 2008; Bonilha et al., 2012; Sobrinho et al., 2013). 
Asymptotic weight $(A)$ and growth rate $(k)$ are considered the two most important parameters from a zootechnical point of view, especially because they possess a biological interpretation and are useful for the identification of animals that are more precocious in terms of production and economically important traits (Brody, 1945). Lopes et al. (2012) fitted four nonlinear models to describe the growth of Nellore cattle from birth to 750 days of age and estimated values of $358 \mathrm{~kg}$ and $0.004 \mathrm{~kg} /$ day for parameters $A$ and $k$, respectively, using the von Bertalanffy model, values lower than those obtained in the present study $(\mathrm{NeC}=0.0071, \mathrm{NeS}=0.0075$ and $\mathrm{NeT}=$ $0.0064 \mathrm{~kg} /$ day). In our study, the model was adjusted for age in months; however, for the purpose of comparison with the literature, $k$ values are discussed using age in days.

The logistic model was used by Paz et al. (2004a) to describe the growth of animals of different genetic compositions ( $1 / 2$ Canchim-Nellore, $1 / 2$ Angus-Nellore, and $1 / 2$ Simmental-Nellore) from 8 to 19 months of age. The authors reported a higher estimated value of parameter $A(489 \mathrm{~kg})$ for $1 / 2$ Simmental-Nellore animals and a parameter $k$ of $0.00599 \mathrm{~kg} / \mathrm{day}$. Compared to that study, the mature weight estimated for the three lines in our study ( $\mathrm{NeC}, \mathrm{NeS}$ and $\mathrm{NeT}$ ) was lower, but the growth rate was higher $(\mathrm{NeC}=0.0071, \mathrm{NeS}=0.0075$, and $\mathrm{NeT}=0.0064 \mathrm{~kg} / \mathrm{day})$. This fact can be explained by the crossing of Nellore animals with large breeds, such as Canchim and Simmental cattle, which tends to produce animals with higher mature weights compared to purebred Nellore animals.

According to the results shown in Table 2, the effect of selection on weight was demonstrated by the differences found between lines. The growth rates $(k)$ measured $(\mathrm{kg} / \mathrm{month})$ were similar for the three lines $(\mathrm{NeC}=0.2165 \mathrm{~kg} / \mathrm{month}(0.0071 \mathrm{~kg} / \mathrm{day}), \mathrm{NeS}=0.2296 \mathrm{~kg} / \mathrm{month}$ $(0.0075 \mathrm{~kg} /$ day $)$, and $\mathrm{NeT}=0.1945 \mathrm{~kg} /$ month $(0.0064 \mathrm{~kg} /$ day $))$. These estimates were higher than those reported in the literature $(0.0019$ to $0.0046 \mathrm{~kg} /$ day) for Nellore cattle (Posada et al., 2011; Lopes et al., 2012). The most likely explanation for this is that males were sent for performance testing following weaning, and were then on pasture during the rainy season, and so had not undergone feed restriction up to 18 months of age, resulting in good weight gain.

The growth curves of BW and $\mathrm{HH}$ showed similar trends. Hip height is an easily measured trait and is more accurate in the determination of body size than live weight or subcutaneous fat, which can show periodic fluctuations depending on the nutritional status and physical state of the animal (Kunkle et al., 1994). Investigators have suggested the use of linear body measures (height, length) in conjunction with weight, to better evaluate animal performance (Northcutt et al., 1992). Several studies reported positive and high (0.53 to 0.87) genetic correlations between weights at different ages and height (Bourdon and Brinks, 1986; Cyrillo et al., 2000; Yokoo et al., 2007). Depending on the intensity applied, selection for weight can result in a medium- to long-term increase in the height of animals.

Using nonlinear models to describe the height of Hereford cattle as a function of age, Espigolan et al. (2013) reported slightly lower values than those estimated here for parameter $A$ (130.9 cm with the logistic model and $131.5 \mathrm{~cm}$ with the Brody model) and much lower values for parameter $k(0.00715$ to $0.00845 \mathrm{~cm} /$ day $)$. The authors observed that height became practically constant by 18 months of age. The same occurred for $\mathrm{HH}$ in the present study, with a decrease in growth by 17 months of age. It is probable that height reaches a stable plateau early compared to other traits, because it is related to the growth of bone tissue, one of the first tissues to develop in the animal (Berg and Butterfield, 1976).

In the present study, the effect of selection line was significant for REA, demonstrating that selection of animals for higher body weight resulted in increased REA. Bonilha et al. (2014), studying animals from the same lines as those used in the present study, also observed higher REA in selected animals, in addition to higher water, protein and mineral content in the carcasses 
of these animals, compared to controls. Water and protein are the main components of muscle tissue, a fact demonstrating the greater potential of selected animals for muscle growth. Bonilha et al. (2014) also observed a higher rate of water deposition in the carcass of selected animals, confirming the greater potential of muscle tissue development as a result of selection. In contrast, in our study, a higher rate $(k)$ of fat deposition in the carcass was detected in $\mathrm{NeC}$ animals, a finding that was probably due to the deceleration of muscle tissue deposition and acceleration of adipose tissue deposition, traits indicated by the inflection point of the growth curve which was reached earlier in control animals because of their smaller size.

The effect of growth traits selection on longissimus dorsi muscle area has been documented in other studies. Altarriba et al. (2005) evaluated the effect of selection for weight at 210 days of age on carcass traits in Pirenaica animals, which resulted in a greater REA. Pinheiro et al. (2012) studied the same lines as used here and reported an increase in the genetic merit of selected Nellore animals (NeS and $\mathrm{NeT}$ ), with an annual genetic gain of 0.14 and $0.12 \mathrm{~cm}^{2}$ in REA at 12 and 18 months of age, respectively.

Soutello et al. (2002) evaluated the development of loin eye area and subcutaneous fat thickness in young bulls (Nellore, $1 / 2$ Angus-Nellore, $1 / 2$ Simmental-Nellore, and Canchim) raised in a feedlot system, and reported significant differences in REA at the beginning of the feedlot period between the genetic groups. However, a decrease in the development of REA was observed by 15 months of age in the four groups. In contrast, other authors have reported linear growth of REA up to 30 months of age (Pineda et al., 2013). In the current study, a decrease in the growth of REA after 15 months of age was evident for all three lines, a fact that was probably due to the change in feed management; animals were submitted to a pasture regimen at the end of the performance test (at approximately 13 months of age).

Studying growth and carcass traits in Hereford cattle from 6 to 24 months of age, Espigolan et al. (2013) estimated values of parameters $A$ and $k$, respectively, of $103.4 \mathrm{~cm}^{2}$ and $0.00167 \mathrm{~cm}^{2} /$ day for REA using the von Bertalanffy model. In the present study, a much lower estimate was obtained for parameter $A$ (around $60 \mathrm{~cm}^{2}$ ) and higher estimates for parameter $k$ (0.0109 to 0.0143 $\mathrm{cm}^{2} /$ day) in the three lines. Although the Nellore breed is considered more delayed than Hereford animals, selection for W378 contributed to the increase in the growth rate of REA, producing animals with a good potential for muscle growth.

In the analysis of RFT in males, a higher value of parameter $A$ was estimated for $\mathrm{NeC}$ animals compared to the $\mathrm{NeS}$ and $\mathrm{NeT}$ lines, probably because of the lower potential of muscle tissue deposition in the former, implying earlier fat deposition than in selected animals. The animals selected for postweaning weight ( $\mathrm{NeS}$ and $\mathrm{NeT}$ ) have a potential for adipose tissue growth as indicated by the values of parameter $k$ (Table 2). This growth was more evident during the period of the performance test (8 to 13 months of age).

Metz et al. (2009) evaluated carcass traits in feedlot-finished crossbred steers (Nellore $\mathrm{x}$ Charolais) with two initial feedlot weights at a mean age of 22 months, and found greater fat thickness and lower hindquarter and muscle quantity in the group of lighter animals compared to heavier animals. In the present study, animals from the control line, which were smaller, exhibited higher values of BFT and RFT than NeS animals, which were always raised in the same environment. In general, animals reaching maturity earlier have a smaller mature size, and consequently enter the phase of fat deposition at lighter weights (Berg and Butterfield, 1976).

Females from the $\mathrm{NeT}$ line exhibited higher BFT and RFT than those from the $\mathrm{NeC}$ and $\mathrm{NeS}$ lines, a finding that was certainly due to the participation of $\mathrm{NeT}$ females in the performance test (2008 to 2011) when these animals received a different diet, while females from the $\mathrm{NeC}$ and $\mathrm{NeS}$ lines, which 
remained on pasture, suffered the effects of the dry season during the postweaning period.

The present results indicate that the selection of animals for postweaning weight may alter some production measures over time, including an increase in animal weight at a certain age, REA and $\mathrm{HH}$, and an apparently slight decrease in fat thickness. According to Archer et al. (1998), the selection of animals for growth rate acts by altering the shape of the growth curve. Therefore, depending on the selection objective, the parameters of the growth curve of a given trait may help identify animals of superior performance.

In conclusion, the selection for postweaning weight alters the growth curves of BW, HH, REA, BFT and RFT in Nellore cattle, resulting in animals with a higher growth potential. The use of curve parameters with biological interpretation ( $A$ and $k$ ) may represent an alternative for the identification of more precocious or productive animals for use in selection and genetic improvement programs.

\section{Conflicts of interest}

The authors declare no conflict of interest.

\section{ACKNOWLEDGMENTS}

To Fundação de Amparo à Pesquisa do Estado de São Paulo (FAPESP), Conselho Nacional de Desenvolvimento Científico e Tecnológico (CNPq) and to Coordenação de Aperfeiçoamento de Pessoal de Nível Superior (CAPES) for financial support.

\section{REFERENCES}

Altarriba J, Varona L, Moreno C, Yagüe G, et al. (2005). Consequences of selection for growth on carcass and meat quality in Pirenaica cattle. Liv. Prod. Sci. 95: 103-114.

Arango JA and van Vleck LD (2002). Size of beef cows: early ideas, new developments. Genet. Mol. Biol. 1: 51-63.

Archer JA, Herd RM, Arthur PF and Parnell PF (1998). Correlated responses in rate of cows and steers to divergent selection for yearling growth rate in Angus cattle. Liv. Prod. Sci. 54: 183-192.

Berg RT and Butterfield RM (1976). New concepts of cattle growth. Sydney University Press, Sydney.

Bonilha SFM, Tedeschi LO, Packer IU, Razook AG, et al. (2008). Evaluation of carcass characteristics of Bos indicus and tropically adapted Bos taurus breeds selected for postweaning weight. J. Anim. Sci. 86: 1770-1780.

Bonilha SFM, Tedeschi LO, de Figueiredo LA, Branco RH, et al. (2012). Carcass traits of Nellore, Caracu, Guzerah and Gir bulls selected for postweaning weight. B. Indústr. Anim. 69: 63-69.

Bonilha EFM, Branco RH, Bonilha SFM, de Araújo FL, et al. (2014). Body chemical composition, tissue deposition rates and gain composition of young Nellore cattle selected for postweaning weight. R. Bras. Zootec. 43: 175-182.

Bourdon RM and Brinks JS (1986). Scrotal circumference in yearling Hereford bulls: Adjustment factors, heritabilities and genetic, environmental and phenotypic relationships with growth traits. J. Anim. Sci. 62: 958-967.

Brody S (1945). Bioenergetics and Growth. Reinhold Publishing Corp., New York.

Brown JE, Fitzhugh HA and Cartwright TC (1976). A comparison of nonlinear models for describing weight-age relationships in cattle. J. Anim. Sci. 42: 810-818.

Cyrillo JNSG, Razook AG, de Figueiredo LA, Neto LMB, et al. (2000). Effects of post-weaning weight selection on body measurements and scrotal perimeter in Nellore males of Sertãozinho (SP). R. Bras. Zootec. 29: 444-453.

Espigolan R, Baldi F, Boligon AA, Banchero G, et al. (2013). Application of nonlinear models to describe the evolution of growth and carcass traits in Hereford cattle. Cienc. Rural 43: 513-519.

Forni S, Piles M, Blasco A, Varona L, et al. (2007). Analysis of beef cattle longitudinal data applying a nonlinear model. J. Anim. Sci. 85: 3189-3197.

Forni S, Piles M, Blasco M, Varona L, et al. (2009). Comparison of different nonlinear functions to describe Nelore cattle growth. J. Anim. Sci. 87: 496-506.

Hartley HO (1961). The modified Gauss-Newton method for the fitting of nonlinear regression functions by least squares. Technometrics 3: 269-280. 
Koch RM, Cundiff LV, Gregory KE and van Vleck LD (2004). Genetic response to selection for weaning weight or yearling weight or yearling weight and muscle score in Hereford cattle: Efficiency of gain, growth, and carcass characteristics. J. Anim. Sci. 82: 668-682.

Kunkle WE, Sand RS and Rae DO (1994). Effect of body condition on productivity in beef cattle. In: Factors affecting calf crop (Fields MJ and Sand RS, eds). CRC Press, Boca Raton, 167-178.

Laird AK (1965). Dynamics of relative growth. Growth 29: 249-263.

Loaiza-Echeverri AM, Bergmann JA, Toral FL, Osorio JP, et al. (2013). Use of nonlinear models for describing scrotal circumference growth in Guzerat bulls raised under grazing conditions. Theriogenology 79: 751-759.

Lopes FB, da Silva MC, Marques EG and McManus CM (2012). Analysis of longitudinal data of beef cattle raised on pasture from northern Brazil using nonlinear models. Trop. Anim. Health Prod. 44: 1945-1951.

MacNeil MD and Northcutt SL (2008). National cattle evaluation system for combined analysis of carcass characteristics and indicator traits recorded by using ultrasound in Angus cattle. J. Anim. Sci. 86: 2518-2524.

Mercadante ME, Packer IU, Razook AG, Cyrillo JNSG, et al. (2003). Direct and correlated responses to selection for yearling weight on reproductive performance of Nelore cows. J. Anim. Sci. 81: 376-384.

Metz PAM, Menezes LFG, Arboitte MZ, Brondani IL, et al. (2009). Different finishing initial weights on carcass and meat characteristics of Nellore $x$ Charolais crossbred steers. R. Bras. Zootec. 38: 346-353.

Nelder A (1961). The fitting of a generalization of the logistic curve. Biometrics 17: 89-110.

Northcutt SL, Wilson DE and Willham RL (1992). Adjusting weight for body condition score in Angus cows. J. Anim. Sci. 70 : 1342-1345.

Paz CCP, Packer IU, Freitas AF, Talhari DT, et al. (2004a). Adjustment of nonlinear models in study of association between genetic polymorphisms and growth in beef cattle. $R$. Bras. Zootec. 33: 1416-1425.

Paz CCP, Packer IU, Freitas AR, Talhari DT, et al. (2004b). Effect of genetic polymorphisms on the growth curve parameters in beef cattle. R. Bras. Zootec. 33: 858-869.

Perotto D, Cue RI and Lee AJ (1992). Comparison of nonlinear functions for describing the growth curve of three genotypes of dairy cattle. Can. J. Anim. Sci. 72: 773-782.

Pineda S, Díaz A, Sepúlveda JC, Ramirez EJ, et al. (2013). After weaning growth curves in Colombian Senepol cattle. Rev. Lasallista Investig. 10: 9-17.

Pinheiro TR, Mercadante MEZ, Albuquerque LG, Bonilha SFM, et al. (2012). Selection for higher body weight in Nelore cattle is effective in achieving an increase of longissimus muscle area without reducing subcutaneous fat thickness. $R$. Bras. Zootec. 41: 1426-1432.

Posada S, Rosero R, Rodríguez N and Costa AC (2011). Estimating parameters of growth curves in Nellore cattle raised in confinement. Rev. MVZ Cordoba 16: 2701-2710.

Quirino CR, Bergmann JA, Vale Filho VR, Andrade VJ, et al. (1999). Evaluation of four mathematical functions to describe scrotal circumference maturation in Nellore bulls. Theriogenology 52: 25-34.

Reverter A, Johnston DJ, Graser HU, Wolcott ML, et al. (2000). Genetic analyses of live-animal ultrasound and abattoir carcass traits in Australian Angus and Hereford cattle. J. Anim. Sci. 78: 1786-1795.

Sobrinho TL, Bonilha SFM, Gonçalves HC, de Castilhos AM, et al. (2013). Feedlot performance, feed efficiency and carcass traits in Nelore cattle selected for postweaning weight. R. Bras. Zootec. 42: 125-129.

Soutello G, Suguisawa L, Silveira AC, et al. (2002). Ribeye area and fat thickness development by ultrasound at superprecoce beef cattle production system. Ciên. Agr. Saúde. FEA 2: 8-12.

von Bertalanffy $L$ (1957). Quantitative laws in metabolism and growth. Q. Rev. Biol. 32: 217-230.

Yokoo MJ, Albuquerque LG, Lobo RB, Sainz RD, et al. (2007). Estimation of genetic parameters for hip height, weight and scrotal circumference in Nelore cattle. R. Bras. Zootec. 36: 1761-1768.

Yokoo MJ, Albuquerque LG, Lobo RB, Bezerra LAF, et al. (2008). Genetic and environmental factors affecting ultrasound measures of longissimus muscle area and backfat thickness in Nelore cattle. Livest. Sci. 117: 147-154. 